\title{
Mineralogical and Petrographic Characteristics of Indium and REE-Bearing Accessory Phases in the Kymi Granite Stock, Southern Finland
}

\author{
Thair Al-Ani', Timo Ahtola', Janne Kuusela', Nadhir Al-Ansari ${ }^{2 *}$ \\ ${ }^{1}$ Geological Survey of Finland (GTK), Espoo, Finland \\ ${ }^{2}$ Lulea University of Technology, Lulea, Sweden \\ Email: *nadhir.alansari@ltu.se
}

How to cite this paper: Al-Ani, T., Ahtola, T., Kuusela, J. and Al-Ansari, N. (2018) Mineralogical and Petrographic Characteristics of Indium and REE-Bearing Accessory Phases in the Kymi Granite Stock, Southern Finland. Natural Resources, 9, 23-41. https://doi.org/10.4236/nr.2018.92003

Received: January 18, 2018

Accepted: February 11, 2018

Published: February 14, 2018

Copyright $\odot 2018$ by authors and Scientific Research Publishing Inc. This work is licensed under the Creative Commons Attribution International License (CC BY 4.0).

http://creativecommons.org/licenses/by/4.0/

\section{(c) (i) Open Access}

\begin{abstract}
The Wiborg rapakivi batholith $(1.64 \mathrm{Ga})$ in southeastern Finland with documented occurrences of $\mathrm{REE}$, indium and $\mathrm{Zn}-\mathrm{Cu}-\mathrm{Pb}$ sulphide mineralization was studied. Hydrothermal greisen and quartz vein type $\mathrm{Fe}-\mathrm{Sn}$ and $\mathrm{Zn}-\mathrm{Cu}-\mathrm{Pb}$ are found in the Kymi granite stock as intrusions. They are enriched with indium and rare earth elements, with roquesite $\left(\mathrm{CuInS}_{2}\right)$ being a major indiumcarrier, whereas monazite $(\mathrm{Ce})$, allanite $(\mathrm{Ce})$, bastnäesite $(\mathrm{Ce})$, xenotime-(Y) and thorite are the main REE carriers. Combination of optical and field emission scanning electron microscopy (FE-SEM) and electron probe microanalysis (EPMA) were used to study the indium and REE-bearing mineral assemblages. EPMA of roquesite found in galena had a composition of $26.16 \% \mathrm{~S}$, $0.02 \% \mathrm{Fe}, 25.06 \% \mathrm{Cu}, 0.03 \% \mathrm{Zn}, 1.06 \% \mathrm{As}, 0.31 \% \mathrm{Sb}$ and $47.14 \% \mathrm{In}$. Substitution reaction $\mathrm{Pb}^{2+} \mathrm{S}^{2-} \leftrightarrow \mathrm{Cu}^{+} \mathrm{In}^{3+} \mathrm{S}^{2-}$ is the cause of the incorporation of indium in the galena structure. The majority of the LREE are carried by monazite, bastnäesite and allanite, and the HREE by xenotime and zircon. There is a partial solid solution between monazite and xenotime with minor or trace amounts of LREE in xenotime grains (6.0 wt\%). LREE ( $>95$ mol\% LREE) and less than 5 mol\% HREE + Y reflects the enrichment of chondrite-normalized REE of the monazite grains of the Kymi granite stock. The xenotime grains (small and irregular) main composition contains 71 - 76 mol\% $\mathrm{YPO}_{4}, 16-27 \mathrm{~mol} \%$ HREE, and 6 - 8 mol\% LREE. It is believed that indium and REE-mineralization presence is due to the combination of magmatic and postmagmatic processes, particularly at later stages by fluid fractionation.
\end{abstract}

\section{Keywords}

Indium, Roquesite, REE-Minerals, Kymi Stock, Finland 


\section{Introduction}

The Wiborg rapakivi batholith $(1.64 \mathrm{Ga})$ in southeastern Finland (Figure 1) is one of a few regions in the Fennoscandian Shield with several documented occurrences of $\mathrm{REE}$, indium and $\mathrm{Zn}-\mathrm{Cu}-\mathrm{Pb}$ sulphide mineralization. Petrological, field observations and many studies on the rapakivi granites in southern Finland, suggest that REE enrichment in the studied rapakivi samples is due to a combination of magmatic and postmagmatic processes (alteration and mineralization), which play an important role in the genesis of REE mineralization [1] [2] [3] [4]. In the Wiborg rapakivi batholith of southeastern Finland, several promising exploration targets have been investigated previously with respect to indium (In) and $\mathrm{Zn}-\mathrm{Cu}-\mathrm{Pb}$ sulphide. The first observation of a mineral with essential indium (roquesite) in the Fennoscandian Shield was that of Burke \& Kieft [5], and not least due to increasing global interest in this rare metal, new discoveries have recently been made, particularly in southeastern Finland [6] [7] [8]. These occurrences include In-bearing magnetite-sphalerite ore (Pahasaari and Getmossmalmen), $\mathrm{Zn}-\mathrm{Cu}$ $\mathrm{Pb}-\mathrm{Ag}$-In-bearing greisen veins (Jungfrubergen) and indium-bearing polymetallic veins in Loviisa. According to these authors, only the sphalerite has shown significant indium contents from the multiple greisen veins of the wiborgite rapakivi granites, which indicates that these veins related to brittle tectonic evolution and associated hydrothermal activity. Indium typically occurs in trace concentrations in copper and zinc sulfide minerals, of which sphalerite is the most important for global indium production, even though chalcopyrite exhibits the highest observed contents [9]. In the Toyoha mine, Japan, the world's largest indium producer in the 1990s - early 2000s, the main carriers of indium besides indium-bearing sphalerite and stannite-kësterite were indeed roquesite together with sakuraiite, chalcopyrite, and a poorly defined Zn-In mineral [10] [11]. An elevated indium contents that were identified at the sulfide-polymetallic and tin-sulfide deposits of Siberia and Far East, Russian; therefore, these deposits are of economic interest. Sphalerite and chalcopyrite and chalcopyrite, bornite, and sphalerite are the major indium carriers in the base-metal massive sulfide and tin-sulfide ores, respectively [12] [13].

The data presented in this study are the outcome of unique set of boreholes drilling during 2014 as part of a critical minerals project carried out by the Geological Survey of Finland (GTK). The study aimed to assess the potential for indium and REE minerals hosted by rapakivi granite and associated rocks in southern Finland. Here, we provide a detailed description of the accessory phases and mineral chemistry of indium and REE-bearing minerals within late-stage intrusions, which is important not only for the Wiborgite rapakivi granites, but also for other granitic complexes in the Palaeoproterozoic bedrock.

\section{Analytical Methods}

Thin sections were prepared from 14 samples of which 12 were selected from topaz-greisen mineralization veins, stockscheider pegmatite and even aplitic 


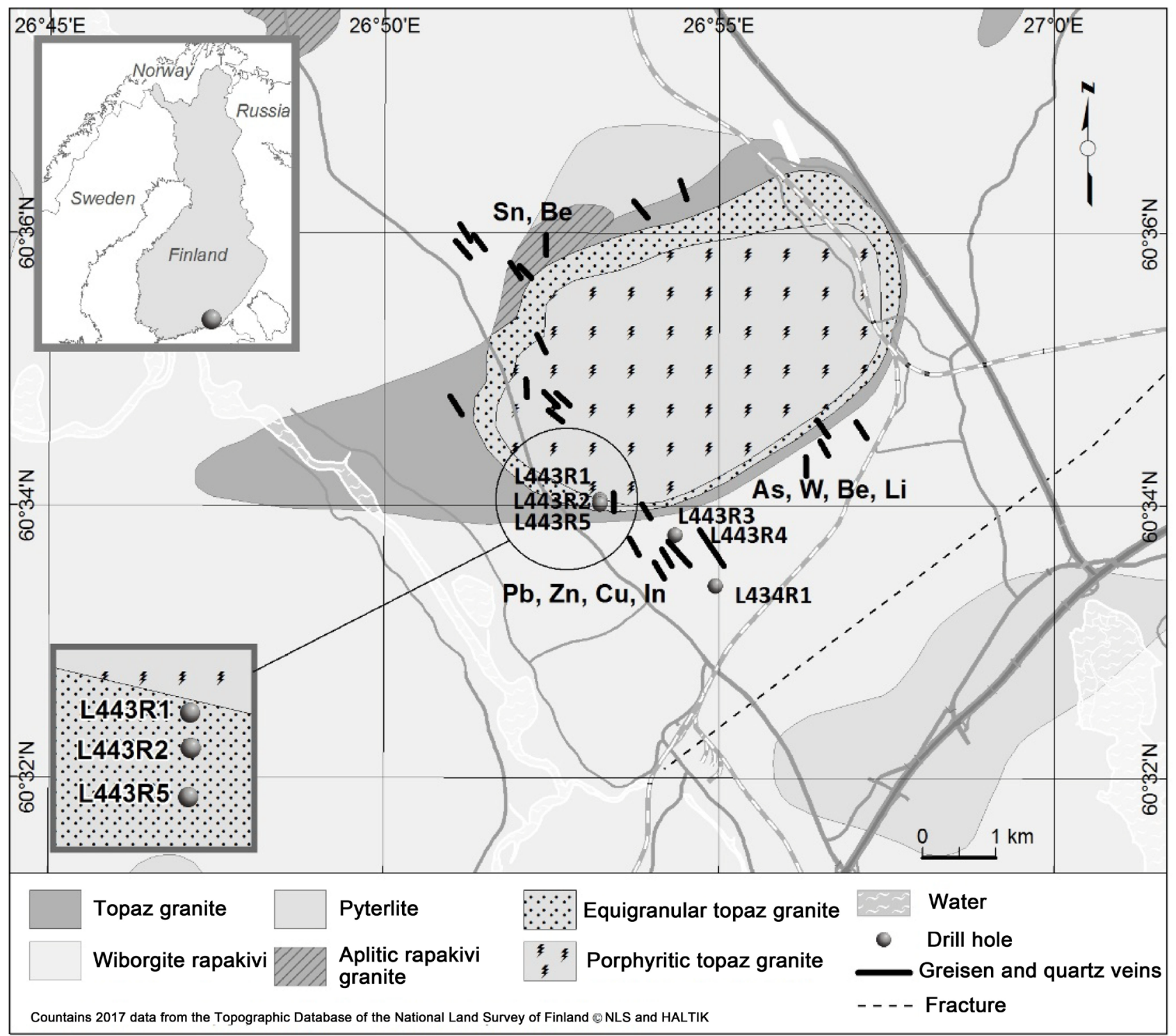

Figure 1. Geological map of the Kymi topaz granite stock in the Wiborg rapakivi batholith, southeastern Finland. The selected borehole locations are marked with gray dots. Modified from Haapala \& Lukkari [26].

granite for mineralogical and petrographical studies. Two samples were selected from $\mathrm{Pb}-\mathrm{Zn}$ - $\mathrm{Cu}$-In dominated quartz veins hosted by Wiborgite rapakivi granites. These samples covered two drilling depth intervals in the drill hole L433R1, between 18.65 to $18.95 \mathrm{~m}$ and 20.75 to 21.10 , respectively (Figure 1 ). The samples were used to identify heavy-mineral contents and were subjected to heavy liquid separation using diiodomethane (density $>3.31 \mathrm{~g} / \mathrm{cm}^{3}$ ).

Petrographic thin sections and polished thin sections of the heavy mineral concentrates were prepared from representative samples in order to investigate the mineralogical-textural characteristics of the indium- and REE-bearing minerals and their host rocks. REE-bearing minerals were identified from polished thin sections by optical microscopy and further by scanning electron microscopy (SEM) and electron microprobe (EMP). 
Backscatter electron images (BSI) and quantitative microanalysis were taken with a JEOL JSM 5900 LV scanning electron microscope equipped with a JED-2300 energy dispersive system at the Electron optical laboratory of GTK, Finland. The operating voltage was fixed at $15 \mathrm{kV}$ with a varying spot size during the qualitative analysis. A total of 20 grains of roquesite (the main host of indium) and REE-bearing minerals (monazite, allanite, bastnäesite and xenotime) were investigated and 320 chemical analyses were carried out using a CAMECA SX100/LKP electron microprobe at the laboratory of the Geological Survey of Finland (GTK), Espoo, Finland. The accelerating voltage was $15 \mathrm{keV}$ with a beam current of $20 \mathrm{nA}$ and a beam size of $5 \mu \mathrm{m}$ respectively. The spot size was $1 \mu \mathrm{m}$ in the analyses without fluorine and $5 \mu \mathrm{m}$ when fluorine was determined.

\section{Results}

\subsection{Petrography and Mineral Chemistry}

The Kymi granite complex consists mainly of three modes of rocks; these include ovoidal alkali feldspar phenocrysts mantled by sodic plagioclase, quartz-feldspar porphyrtic texture with angular shape phenocrysts and porphyritic hornblende rapakivi texture composed of plagioclase feldspar, K-feldspar, quartz, biotite and hornblende [4] [14].

\subsubsection{Accessory Minerals}

Apatite (AP) is present in most of the studied samples as disseminations biotite, quartz and feldspar or in contact with zircon, sulphides, chlorite and REE-bearing minerals. A BSI image of some apatite crystals shows an approximately hexagonal basal section, $70 \mu \mathrm{m}$ in diameter (Figure 2(a)). It was also commonly observed as inclusions within zircon (Figure 2(b)). Apatite grains (fluorapatite mainly) are characterized by higher $\mathrm{Ca}(53.5-54.2 \mathrm{wt} \% \mathrm{CaO}$ ) and no significant contents concentrations of those trace elements (e.g. REEs, Y, Sr, Th, and U). In addition, apatite crystals are also very rich in phosphate4 (2.0 - 43.5 wt $\left.\% \mathrm{P}_{2} \mathrm{O}_{5}\right)$ and halogens (4.2 - $5.5 \mathrm{wt} \%, \mathrm{~F}$ ) as listed in Table 1.

Fluorite (Fl): The late greisen mineralization veins of Kymi granite stock formed fluorite-rich hydrothermal fluids [15]. These high temperature fluids are characterized by the close association of $\mathrm{Y}$ and REE metal. Fluorite $\left(\mathrm{CaF}_{2}\right)$ occurs coarse, well-formed to subhedral crystals and contains large clusters of cassiterite and bastnäsite crystals (Figure 2(c)). Fluorite is found as a common gangue mineral in hydrothermal veins, especially those containing lead (galena) and zinc (sphalerite) minerals (Figure 2(e)). Multigrain of analyses demonstrates that fluorite is composed mainly of $\mathrm{CaO}$ (70.9 - 74.9 wt\%) and $\mathrm{F}$ (41.2 - 46.9 wt\%), with traces of $\mathrm{Al}, \mathrm{Sr}$ and $\mathrm{Fe}$ as shown in Table 1.

Cassiterite (Cst) is the main Sn-bearing mineral concentrator of Sn in the studied Kymi granite stock, southern Finland. It occurs as small bright grains or as inclusions within fluorite (Fl) (Figure 2(c)). The cassiterite crystals were separated by heavy liquid separation (HLS), and found to occur as short pyramidal 

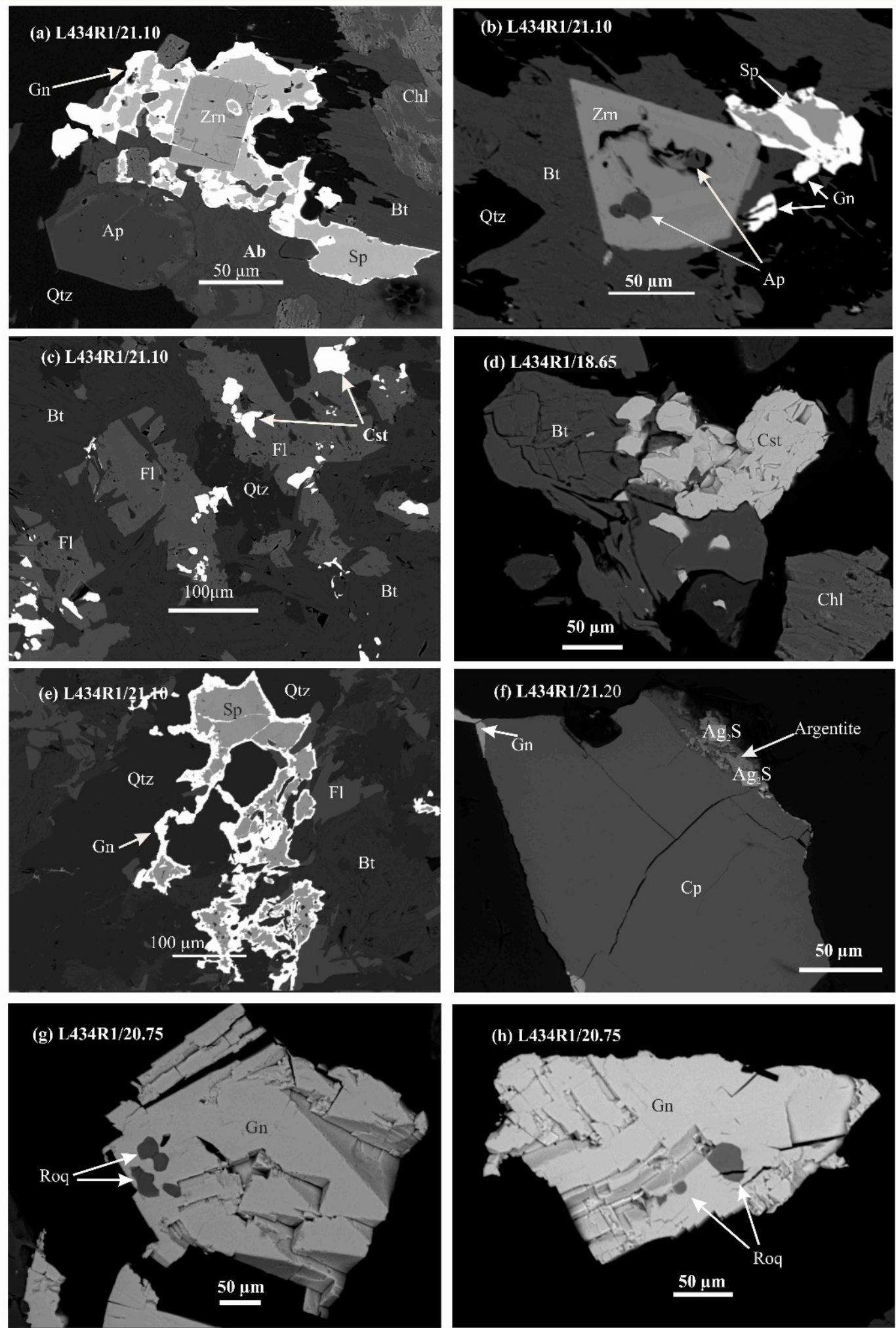

Figure 2. BSE images of accessory and REE-bearing minerals in studied samples. (a) Hexagonal apatite (Ap) and euhedral zircon (Zrn) associated with sulphides; (b) Euhedral zircon (Zrn) with apatite inclusions, both in contact with biotite and sulphides; (c) Bright cassiterite (Cst) grains clustering within fluorite (Fl); (d) Cassiterite (Cst) associated with biotite; (e) Galena (Gn) forming a replacement texture around sphalerite $(\mathrm{Sp})$; (f) Galena $(\mathrm{Gn})$ and argentite $(\mathrm{Ag})$ occurring as replacement rims on chalcopyrite (Cp); ((g), (h)) Subhedral to anhedral roquesite (Roq) grains embedded in galena. 
Table 1. Representative electron microprobe analysis of apatite and fluorite from the Kymi granite stocks, wt\%.

\begin{tabular}{|c|c|c|c|c|c|c|c|c|c|}
\hline No. & Sample & $\mathrm{Al}_{2} \mathrm{O}_{3}$ & $\mathrm{FeO}$ & $\mathrm{CaO}$ & $\mathrm{SrO}$ & $\mathrm{P}_{2} \mathrm{O}_{5}$ & $\mathrm{~F}$ & ${ }^{*}-\mathrm{O}=\mathrm{F}$ & Total \\
\hline \multicolumn{10}{|c|}{ Apatite } \\
\hline 1 & L434R1/18.95 & 0.04 & 0.01 & 54.04 & 0.11 & 42.27 & 4.87 & -2.05 & 99.62 \\
\hline 2 & L434R1/18.95 & 0.00 & 0.00 & 54.19 & 0.10 & 42.01 & 4.97 & -2.09 & 99.27 \\
\hline 3 & $\mathrm{~L} 434 \mathrm{R} 1 / 21.10$ & 0.00 & 0.02 & 53.72 & 0.05 & 42.22 & 5.54 & -2.33 & 99.43 \\
\hline 4 & L443R3/150.4 & 0.00 & 0.06 & 53.48 & 0.06 & 43.49 & 4.14 & -1.74 & 100.13 \\
\hline 5 & L443R3/150.4 & 0.00 & 0.05 & 53.62 & 0.04 & 42.46 & 4.93 & -2.07 & 99.63 \\
\hline \multicolumn{10}{|c|}{ Fluorite } \\
\hline 6 & L434R1/20.95 & 0.43 & 0.00 & 70.91 & 0.05 & 0.00 & 46.86 & -19.73 & 98.59 \\
\hline 7 & L434R1/20.95 & 0.01 & 0.21 & 72.87 & 0.06 & 0.00 & 44.08 & -18.56 & 98.72 \\
\hline 8 & $\mathrm{~L} 434 \mathrm{R} 1 / 21.10$ & 0.01 & 0.03 & 72.87 & 0.10 & 0.00 & 41.94 & -17.66 & 97.32 \\
\hline 9 & $\mathrm{~L} 434 \mathrm{R} 1 / 21.10$ & 0.03 & 0.00 & 74.89 & 0.10 & 0.00 & 41.36 & -17.42 & 98.98 \\
\hline 10 & L434R1/21.10 & 0.00 & 0.02 & 74.02 & 0.03 & 0.00 & 41.19 & -17.35 & 97.97 \\
\hline
\end{tabular}

Note: ${ }^{*}-\mathrm{O}=\mathrm{F}$ : The equivalent of oxygen for halogens was accounted by subtracting it from the total calculated oxides.

Table 2. Representative microprobe analysis of cassiterite from the Kymi granite stocks, wt $\%$.

\begin{tabular}{cccccccc}
\hline No. & Sample & $\mathrm{TiO}_{2}$ & $\mathrm{FeO}$ & $\mathrm{Nb}_{2} \mathrm{O}_{5}$ & $\mathrm{In}_{2} \mathrm{O}_{3}$ & $\mathrm{SnO}_{2}$ & $\mathrm{Total}$ \\
\hline 1 & $\mathrm{~L} 434 \mathrm{R} 1 / 21.10$ & 0.77 & 0.57 & 0.0179 & 0.0114 & 98.32 & 99.69 \\
2 & $\mathrm{~L} 434 \mathrm{R} 1 / 21.10$ & 0.68 & 0.49 & 0.0079 & 0.0047 & 97.80 & 98.98 \\
3 & $\mathrm{~L} 434 \mathrm{R} 1 / 21.10$ & 0.72 & 0.27 & 0.2494 & 0.0100 & 98.65 & 99.90 \\
4 & $\mathrm{~L} 434 \mathrm{R} 1 / 21.10$ & 0.46 & 0.38 & 0.7630 & 0.0026 & 98.13 & 99.74 \\
\hline
\end{tabular}

crystals about $100 \mu \mathrm{m}$ in length, and in contact with biotite (Figure 2(d)). The crystals of cassiterite from the studied samples are homogeneous in composition and consist of nearly pure $\mathrm{SnO}_{2}\left(>98 \mathrm{wt} \%\right.$ ) with small amounts of $\mathrm{Nb}_{2} \mathrm{O}_{5}, \mathrm{TiO}_{2}$ and $\mathrm{FeO}$ (total content $>2 \mathrm{wt} \%$ ). Furthermore, there is no important indium enrichment in the selected cassiterite grains $\left(\operatorname{In}_{2} \mathrm{O}_{3}\right.$ between 0.0114 to 0.0047 wt\%) (Table 2).

Sulphides: Most widespread sulphide minerals found in the studied wiborgite rapakivi granites are sphalerite $(\mathrm{Sp})$, galena $(\mathrm{Gn})$ and chalcopyrite $(\mathrm{Cp})$ are the dominants sulphide phases. Galena and sphalerite are intimately intergrowth and develop a rim replacement texture of sphalerite-galena (Figure 2(a), Figure 2(e)). Chalcopyrite occurs as an individual crystal and commonly associated with acanthite $\left(\mathrm{Ag}_{2} \mathrm{~S}\right)$ and galena $(\mathrm{PbS})$ (Figure $2(\mathrm{f})$ ). The number of galena crystals with an octahedral shape and other sulphide grains was derived from heavy mineral assemblages of the two samples, L433 R1/18.95 and L433 R1/21.10. The FE-SEM-EDS examination of multiple galena grains established overgrowth development of large early octahedral-cubic crystals by numerous smaller cubic crystals with triangular symmetry and a size below $500 \mu \mathrm{m}$ (Figure 2(g), Figure 2(h)). Inclusions of an indium-bearing mineral (roquesite) sometimes occur in 
galena, mostly as later sulphide phases, in selected rapakivi granite samples (Figure 3(a), Figure 3(b)). The chemical composition of the sulphide minerals obtained by EPMA is given in Table 3. The chemical determinations confirmed that $\mathrm{Zn}, \mathrm{Fe}, \mathrm{Ag}, \mathrm{Sb}$ and $\mathrm{Bi}$ are the most important minor elements and have an uneven distribution in the studied galena.

\subsubsection{Indium and REE-Bearing Minerals}

The indium and REE-bearing mineral assemblages were investigated in polished thin sections of separated heavy mineral and petrographic thin sections by using a combination of a combination of optical and electronics microscopies (SEM\& EPMA). Roquesite is a major indium carrier, while monazite, bastnäesite, allanite and xenotime are the dominant light rare earth element (LREE) minerals studied Kymi granite stock, southern Finland.

Roquesite (Roq) is a major indium carrier (ideal formula CuInS2) from the Kymi granite complex. It mainly occurs as $10-30-\mu \mathrm{m}$ subhedral to anhedral, often found as angular crystals in galena (Figure $2(\mathrm{~g})$, Figure $2(\mathrm{~h})$ ). Overall, the mineral appears to be relatively widespread, yet not abundant; it has been observed within a two-metre section of the drill core sample from the studied section L434R1/20.75 - $21.10 \mathrm{~m}$, and some of roquesite appear as several individual

Table 3. Representative microprobe analysis of sulphide minerals from the Kymi granite stocks, wt $\%$.

\begin{tabular}{|c|c|c|c|c|c|c|c|c|c|c|c|c|c|}
\hline No. & Sample & $S$ & $\mathrm{Cu}$ & $\mathrm{Fe}$ & $\mathrm{Ni}$ & Co & $\mathrm{Zn}$ & $\mathrm{Sb}$ & $\mathrm{Bi}$ & $\mathrm{Cd}$ & $\mathrm{Pb}$ & $\mathrm{Ag}$ & Total \\
\hline \multicolumn{14}{|c|}{ Galena } \\
\hline 2 & L434R1/20.95 & 13.14 & 0.00 & 0.29 & 0.00 & 0.00 & 2.28 & 0.01 & 0.31 & 0.02 & 82.28 & 0.01 & 98.35 \\
\hline 3 & L434R1/20.95 & 13.06 & 0.03 & 0.20 & 0.00 & 0.00 & 3.15 & 0.03 & 0.16 & 0.07 & 81.82 & 0.00 & 98.53 \\
\hline 4 & L434R1/20.95 & 13.19 & 0.02 & 0.29 & 0.00 & 0.02 & 2.81 & 0.00 & 0.30 & 0.02 & 82.22 & 0.00 & 98.88 \\
\hline 5 & L434R1/20.95 & 12.99 & 0.00 & 0.25 & 0.00 & 0.00 & 2.45 & 0.00 & 0.20 & 0.01 & 84.17 & 0.02 & 100.09 \\
\hline 6 & L434R1/18.95 & 13.19 & 0.00 & 0.01 & 0.01 & 0.01 & 0.03 & 0.00 & 0.19 & 0.01 & 85.28 & 0.00 & 98.75 \\
\hline 7 & L434R1/18.95 & 13.42 & 0.00 & 0.00 & 0.00 & 0.00 & 0.58 & 0.00 & 0.29 & 0.05 & 83.98 & 0.01 & 98.32 \\
\hline \multicolumn{14}{|c|}{ Sphalerite } \\
\hline 8 & L434R1/20.95 & 33.54 & 0.01 & 0.21 & 0.00 & 0.00 & 65.58 & 0.00 & 0.00 & 0.24 & 0.00 & 0.00 & 99.59 \\
\hline 9 & L434R1/20.95 & 33.58 & 0.00 & 0.22 & 0.00 & 0.00 & 64.43 & 0.00 & 0.00 & 0.23 & 0.03 & 0.00 & 98.49 \\
\hline 10 & L434R1/20.95 & 33.71 & 0.00 & 0.20 & 0.00 & 0.01 & 65.21 & 0.00 & 0.00 & 0.18 & 0.09 & 0.00 & 99.40 \\
\hline 11 & L434R1/21.10 & 34.22 & 0.01 & 0.13 & 0.01 & 0.00 & 63.66 & 0.00 & 0.10 & 0.37 & 0.06 & 0.00 & 98.58 \\
\hline 12 & L434R1/21.10 & 34.15 & 0.00 & 0.15 & 0.00 & 0.01 & 63.26 & 0.02 & 0.00 & 0.31 & 0.10 & 0.00 & 98.02 \\
\hline 13 & L434R1/21.10 & 34.23 & 0.01 & 0.15 & 0.01 & 0.00 & 63.00 & 0.00 & 0.00 & 0.34 & 0.02 & 0.00 & 97.79 \\
\hline \multicolumn{14}{|c|}{ Chalcopyrite } \\
\hline 14 & L434R1/21.10 & 34.52 & 32.80 & 30.27 & 0.00 & 0.00 & 0.00 & 0.00 & 0.03 & 0.00 & 0.35 & 0.00 & 97.97 \\
\hline 15 & L434R1/21.10 & 34.58 & 33.07 & 30.37 & 0.00 & 0.00 & 0.00 & 0.00 & 0.00 & 0.00 & 0.42 & 0.00 & 98.45 \\
\hline
\end{tabular}


fine grains/crystals within the galena (Figure 3(a), Figure 3(b)). However, the anomalously high In (886 ppm) and Zn (2470 ppm) of sample L434R1 (20.75 21.10) suggests the presence of minute inclusions of roquesite. The roquesite of the studied Kymi granite stock is relatively homogeneous in composition, and the EPMA analytical data (25-point analyses from 20 different grains/crystals in section L434R1/20.75 - $21.10 \mathrm{~m}$ ) presented in relation to an ideal composition (Table 4). Higher contents of indium (46.57 to $47.61 \mathrm{wt} \%$ ) in the studied roquesite are closely associated with $\mathrm{Cu}, \mathrm{Zn}, \mathrm{As}, \mathrm{Sb}$ and $\mathrm{Fe}$. Copper is present in roquesite, most commonly at concentrations between $24.62-25.32 \mathrm{wt} \%$. Arsenic (As) and antimony ( $\mathrm{Sb}$ ) comprise trace components, ranging from 0.95 to 1.31 wt\% As and 0.17 to $0.43 \mathrm{wt} \% \mathrm{Sb}$, respectively, whereas $\mathrm{Fe}$ and $\mathrm{Zn}$ contents are negligible.

Monazite (Mnz) occurs as euhedral to subhedral crystals (diameter 50 - $100 \mu \mathrm{m}$ ) in mineralized greisen of Kymi granite. Monazite was found association with xenotime, needle-shaped bastnäesite and fluorite (Figure 3(c), Figure 3(d)); and (2) as inclusions within xenotime (Figure 3(e)), or as irregular, sub-rounded and small grains (diameter $10-40 \mu \mathrm{m}$ ), mainly associated with apatite and xenotime (Figure 3(f)). Monazite preferentially incorporates the light rare elements LREE, and xenotime incorporates the heavy rare earth elements HREE and Y. The chemical analysis of monazite revealed the contents of the major oxides to be as follows: $\mathrm{P}_{2} \mathrm{O}_{5}$ (27.7 to $29.3 \mathrm{wt} \%$ ), $\mathrm{F}$ (1.0 to $1.6 \mathrm{wt} \%$ ), $\mathrm{Ce}_{2} \mathrm{O}_{3}$ (31.4 to $34.4 \mathrm{wt} \%$ ), $\mathrm{La}_{2} \mathrm{O}_{3}$ (11.7 to $15.4 \mathrm{wt} \%$ ), $\mathrm{Nd}_{2} \mathrm{O}_{3}$ (11.3 to $13.5 \mathrm{wt} \%$ ), $\mathrm{Sm}_{2} \mathrm{O}_{3}$ (1.3 to $2.7 \mathrm{wt} \%$ ), $\mathrm{Gd}_{2} \mathrm{O}_{3}$ (1 to $2.2 \mathrm{wt} \%$ ) and $\mathrm{Pr}_{2} \mathrm{O}_{3}$ (3.0 to $3.6 \mathrm{wt} \%$ ). Monazite grains are variable in their $\mathrm{Th}, \mathrm{U}$ and $\mathrm{Si}$ content, $\mathrm{ThO}_{2}$ varies from 0.53 to $3.1 \mathrm{wt} \%, \mathrm{UO}_{2}$ has a low content that ranges from 0.01 to $0.24 \mathrm{wt} \%$ and $\mathrm{SiO}_{2}$ varies between 0.5 and 3.2 wt $\%$. HREE contents are low and variable compared with LREE $\left(\mathrm{Dy}_{2} \mathrm{O}_{3}\right.$ between 0.32 to $0.54 \mathrm{wt} \%$ and $\mathrm{Yb}_{2} \mathrm{O}_{3}$ about $0.1 \mathrm{wt} \%$ ). $\mathrm{Y}_{2} \mathrm{O}_{3}$ is correspondingly low (1.12 to $1.90 \mathrm{wt} \%)$ and inversely correlated with $\mathrm{ThO}_{2}$ (Table 5 ). The higher grade metamorphic and related igneous rocks are the best source areas for monazites with a high thorium content [16]. Monazites with low Th are common in rocks that have experienced significant fluid involvement, including authigenic precipitation (e.g., [17]) or as hydrothermal precipitates (e.g., [18]). It becomes clear, that the low Th content in the monazite from the mineralization greisen and quartz vein in The Kymi granite stock is indicative of hydrothermal origin of alteration.

Bastnäesite (Bsn) in the studied rapakivi granite is mostly present as acicular or needle-shaped crystals forming either radial accumulations or intricate crosscutting grids within a variety of minerals such as monazite, fluorite and biotite (Figure 3(c)). It forms needle-like aggregates of crystals in small cavities or occurs as fillings of thin fractures in fluorite and quartz (Figure 3(g)). In some cases, it is found as a replacement of allanite. It appears that a bright bastnäesite ring (Figure $3(\mathrm{~h})$ ) replaced the outer rims of the former allanite. The presence of fluorite, and REE bearing minerals (allanite, bastnäesite) in most fluorite-rich samples is indicative to fractionated of lanthanides (rare-earth elements, REE) in 

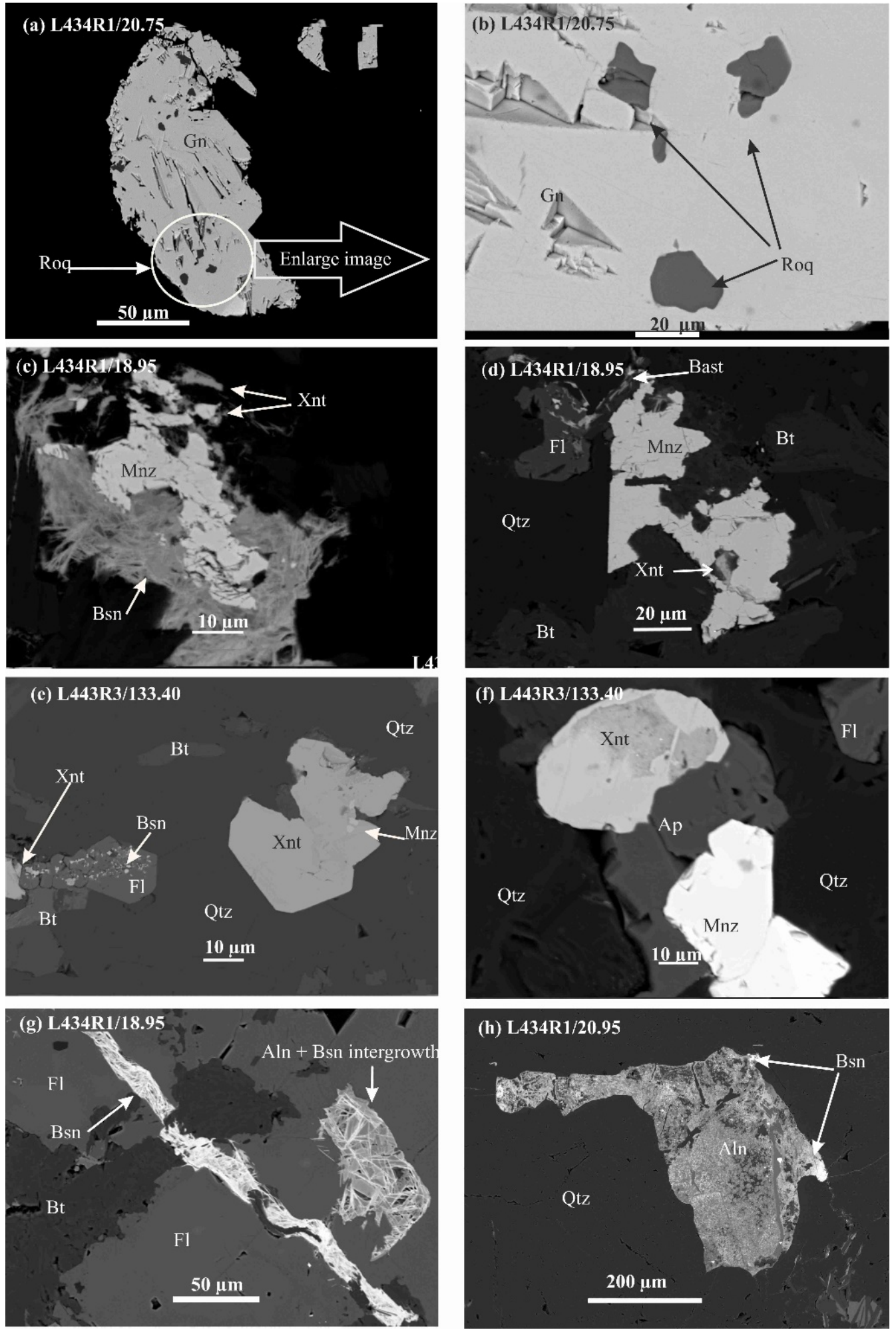

Figure 3. BSE images of indium and REE-bearing minerals in studied samples. ((a), (b)) Roquesite (Roq) grains occur in galena, and the images enlarged to emphasize the roquesite grains; (c) Monazite (Mnz) enclosed by acicular crystals of bastnäesite (Bsn) and associated with xenotime (Xnt); (d) Coarse and anhedral monazite (Mnz) with inclusions of xenotime (Xnt); (e) Subhedral xenotime contains smaller monazite grains inclusions. In the left side of image, the xenotime is in contact with fluorite and bastnäesite; (f) Xenotime (Xnt) and monazite (Mnz) in contact with apatite, all embedded in quartz; (g) Needle-like crystals of bastnäesite (Bsn) filling vugs and fractures within fluorite; (h) Allanite (Aln) with bastnäesite (Bsn) overgrowth in the rim of the grain. 
Table 4. Representative electron microprobe analysis of roquesite from drill core L434R1 with the drilling interval depth between 20.75 - $21.10 \mathrm{~m}$ in Kymi granite stocks, wt\%.

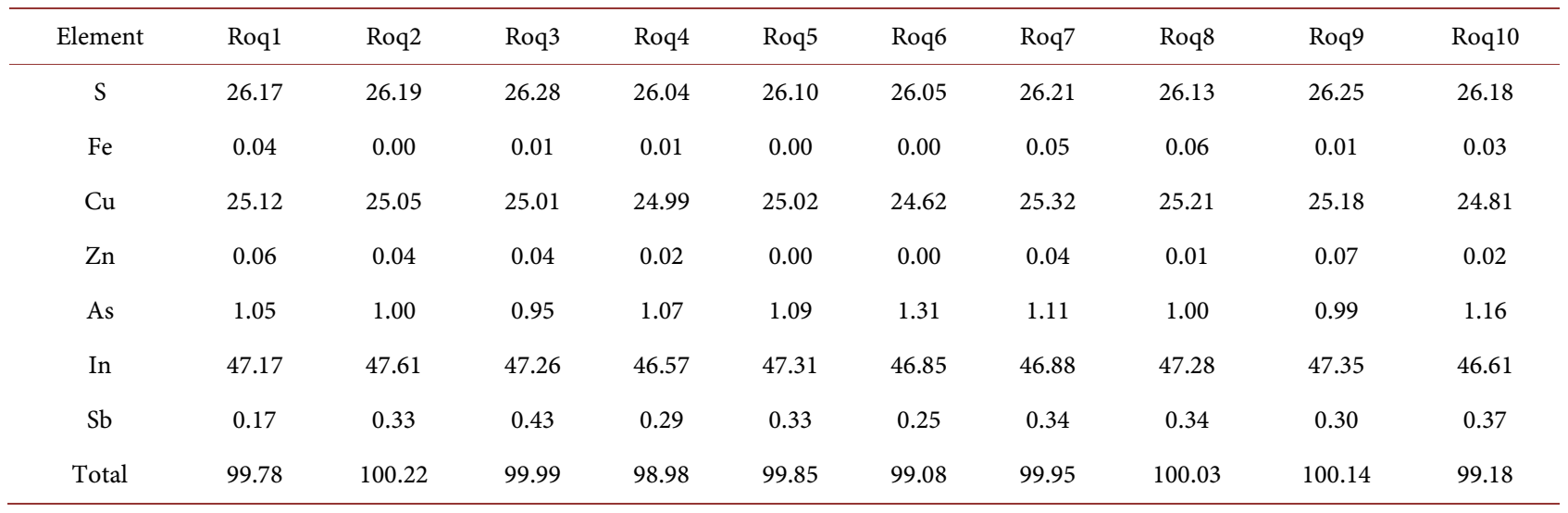

fluorine-rich hydrothermal solutions resulting in the deposition of REE-minerals (allanite, bastnäesite) and fluorite [19]. Multigrain analyses demonstrate that the bastnäesite-(Ce) is rich in LREE ( 65\%), occurring as $\mathrm{Ce}_{2} \mathrm{O}_{3}$ (30.6 to $33.7 \mathrm{wt} \%$ ), $\mathrm{La}_{2} \mathrm{O}_{3}$ (12.9 to $\left.17.9 \mathrm{wt} \%\right), \mathrm{Nd}_{2} \mathrm{O}_{3}$ (7.3 to $11.6 \mathrm{wt} \%$ ), $\mathrm{Sm}_{2} \mathrm{O}_{3}$ (0.8 to $2.0 \mathrm{wt} \%$ ), $\mathrm{Gd}_{2} \mathrm{O}_{3}$ (0.7 to $\left.1.7 \mathrm{wt} \%\right), \mathrm{Pr}_{2} \mathrm{O}_{3}$ (2.5 to $3.2 \mathrm{wt} \%$ ) and $\mathrm{F}$ (6.7 to $9.3 \mathrm{wt} \%$ ). Bastnäesite grains also revealed the presence of HREE (0.5 to $1.5 \mathrm{wt} \%$ ), $\mathrm{ThO}_{2}$ (0.3 to 1.3 $\mathrm{wt} \%$ ) and $\mathrm{Y}_{2} \mathrm{O}_{3}$ (1.7 to $3.4 \mathrm{wt} \%$ ) (Table 5). The overwhelming presence of fluorite, REE bearing minerals, the alkaline nature of the igneous phases, carbonate flooding, sodic and potassic alteration in the district has led some authors to call upon a hidden carbonatite as the REE metal source and hydrothermal heat source (Schreiner, 1993 and McLemore, 2010).

Allanite (Aln) analysed in the present study (Figure 3(h)) has an almost rectangular shape $(400 \mu \mathrm{m})$, with irregular subhedral contacts with biotite $(\mathrm{Bt})$ and, more externally, quartz $(\mathrm{Qtz})$. Allanite is enriched in REE, particularly the light REE (Ce, La, Pr and Nd), and shows a relatively uniform composition with 31 $42 \mathrm{wt} \% \mathrm{REE}_{2} \mathrm{O}_{3}, \sim 19-21 \mathrm{wt} \% \mathrm{SiO}_{2}, \sim 10-12 \mathrm{wt} \% \mathrm{Al}_{2} \mathrm{O}_{3}, \sim 6-8 \mathrm{wt} \% \mathrm{FeO}$ and $\sim 6$ - $8 \mathrm{wt} \% \mathrm{CaO}$. Some allanite grains show a significantly greater $\mathrm{Y}_{2} \mathrm{O}_{3}$ concentration (5 - $6 \mathrm{wt} \%$ ) and $\mathrm{ThO}_{2}$ concentration (1.6 - $2.0 \mathrm{wt} \%$ ), while all the allanite compositions show a predominance of Ce over the other REE concentrations (Table 5).

Xenotime (Xnt) is extremely rare and identified as euhedral to anhedral grains $(10-50 \mu \mathrm{m}$ ) embedded in quartz (Figure $3(\mathrm{e})$ ). Xenotime is much more commonly intergrown with monazite (Figure $3(\mathrm{f})$ ), sometimes as inclusions of monazite (Figure $3(\mathrm{~d})$ ). The average contents of major oxides in xenotime (Xnt) obtained by EMPA analysis are as follows: $\mathrm{P}_{2} \mathrm{O}_{5}(32 \mathrm{wt} \%), \mathrm{Yb}_{2} \mathrm{O}_{3}(42 \mathrm{wt} \%)$, LREE (6.0 wt\%), HREE (14 wt\%) and a low content of $\mathrm{ThO}_{2}$ and $\mathrm{UO}_{2}(0.3 \mathrm{wt} \%$ for each) (Table 5). Monazite and xenotime in the late-stage intrusions of the Kymi granite stock also occur in the monazite-xenotime solid solution, which indicates the presence of hydrothermal solutions highly enriched in REE, Y, P, F and Sn. Hydrothermal and solid solutions can be distinguished by a high content of 
Table 5. Chemical composition of LREE-bearing minerals from the Kymi granite stocks, wt\%.

\begin{tabular}{|c|c|c|c|c|c|c|c|c|c|c|}
\hline \multirow{2}{*}{$\begin{array}{l}\text { Sample } \\
\text { Mineral }\end{array}$} & \multicolumn{2}{|c|}{ L443R3/137.6 } & \multicolumn{2}{|c|}{ L434R1/18.95 } & \multicolumn{3}{|c|}{ L434R1/21.10 } & \multicolumn{3}{|c|}{ L434R1/20.95 } \\
\hline & Mnz1 & Mnz2 & Mnz3 & Mnz4 & Bsn1 & Bsn 2 & Bsn 3 & Aln1 & $A \ln 2$ & $A \ln 3$ \\
\hline $\mathrm{SiO}_{2}(\mathrm{wt} \%)$ & 1.53 & 0.93 & 2.89 & 3.21 & 1.86 & 2.26 & 2.80 & 30.16 & 31.40 & 32.22 \\
\hline $\mathrm{P}_{2} \mathrm{O}_{5}$ & 27.58 & 27.69 & 28.43 & 28.36 & 0.14 & 0.09 & 0.10 & 0.14 & 0.05 & 0.19 \\
\hline $\mathrm{CaO}$ & 0.39 & 0.20 & 0.25 & 0.24 & 8.99 & 7.49 & 6.19 & 11.79 & 10.52 & 10.68 \\
\hline $\mathrm{TiO}_{2}$ & n.d & n.d. & n.d & n.d & n.d & $\mathrm{n}, \mathrm{d}$. & n.d & 1.27 & 1.32 & 1.27 \\
\hline $\mathrm{Al}_{2} \mathrm{O}_{3}$ & n.d & n.d. & n.d & n.d & n.d & $\mathrm{n}, \mathrm{d}$. & n.d & 10.29 & 10.67 & 10.19 \\
\hline $\mathrm{FeO}$ & n.d & n.d. & n.d & n.d & n.d & $\mathrm{n}, \mathrm{d}$. & n.d & 10.30 & 9.59 & 8.84 \\
\hline $\mathrm{UO}_{2}$ & 0.21 & 0.07 & 0.05 & 0.03 & 0.02 & 0.00 & 0.05 & 0.03 & 0.05 & 0.00 \\
\hline $\mathrm{ThO}_{2}$ & 3.40 & 3.21 & 1.59 & 1.53 & 3.82 & 0.36 & 1.20 & 0.80 & 1.32 & 1.51 \\
\hline $\mathrm{Y}_{2} \mathrm{O}_{3}$ & 1.43 & 1.00 & 1.20 & 1.59 & 2.41 & 1.74 & 3.44 & 0.09 & 0.04 & 0.09 \\
\hline $\mathrm{Ce}_{2} \mathrm{O}_{3}$ & 30.75 & 30.04 & 33.11 & 33.00 & 22.23 & 33.68 & 31.66 & 18.39 & 20.10 & 20.39 \\
\hline $\mathrm{Nd}_{2} \mathrm{O}_{3}$ & 12.83 & 10.35 & 12.25 & 12.49 & 7.82 & 11.64 & 11.14 & 5.99 & 5.13 & 5.89 \\
\hline $\mathrm{La}_{2} \mathrm{O}_{3}$ & 12.33 & 11.82 & 13.20 & 13.58 & 10.43 & 17.94 & 13.70 & 7.99 & 7.19 & 6.37 \\
\hline $\mathrm{Pr}_{2} \mathrm{O}_{3}$ & 3.27 & 3.30 & 3.57 & 3.37 & 2.19 & 3.23 & 2.95 & 0.65 & 1.02 & 0.76 \\
\hline $\mathrm{Sm}_{2} \mathrm{O}_{3}$ & 1.99 & 2.07 & 2.22 & 1.92 & 1.11 & 1.33 & 1.99 & 0.41 & 0.51 & 0.38 \\
\hline $\mathrm{Gd}_{2} \mathrm{O}_{3}$ & 1.51 & 1.34 & 1.55 & 1.43 & 0.95 & 0.80 & 1.72 & 0.11 & 0.25 & 0.08 \\
\hline $\mathrm{Dy}_{2} \mathrm{O}_{3}$ & 0.45 & 0.26 & 0.45 & 0.56 & 0.55 & 0.22 & 0.79 & 1.40 & 1.37 & 1.65 \\
\hline $\mathrm{Ho}_{2} \mathrm{O}_{3}$ & 0.08 & 0.01 & 0.00 & 0.00 & 0.00 & 0.06 & 0.00 & n.d. & n.d. & n.d. \\
\hline $\mathrm{Er}_{2} \mathrm{O}_{3}$ & 0.10 & 0.12 & 0.03 & 0.10 & 0.18 & 0.17 & 0.29 & 0.17 & 0.01 & 0.30 \\
\hline $\mathrm{Yb}_{2} \mathrm{O}_{3}$ & 0.01 & 0.00 & 0.00 & 0.00 & 0.05 & 0.00 & 0.03 & 0.05 & 0.00 & 0.14 \\
\hline $\mathrm{Lu}_{2} \mathrm{O}_{3}$ & 0.00 & 0.00 & 0.02 & 0.15 & 0.03 & 0.07 & 0.04 & 0.21 & 0.05 & 0.00 \\
\hline REE & 63.33 & 59.32 & 66.41 & 66.59 & 45.56 & 69.14 & 64.31 & 35.37 & 35.63 & 35.95 \\
\hline $\mathrm{F}$ & 1.05 & 0.93 & 1.97 & 1.07 & 9.01 & 8.01 & 6.71 & 0.47 & 0.51 & 0.50 \\
\hline Total & 97.95 & 99.11 & 100.88 & 101.64 & 72.03 & 89.33 & 84.89 & 100.29 & 100.59 & 100.96 \\
\hline \multicolumn{11}{|c|}{ Structural formulae based on 4 oxygen atoms } \\
\hline Si (apfu) & 0.15 & 0.10 & 0.25 & 0.28 & 0.17 & 0.20 & 0.27 & 1.19 & 1.22 & 1.24 \\
\hline $\mathrm{P}$ & 1.12 & 1.20 & 1.04 & 1.05 & 0.01 & 0.00 & 0.00 & 0.00 & 0.00 & 0.00 \\
\hline $\mathrm{Ca}$ & 0.04 & 0.02 & 0.02 & 0.02 & 0.90 & 0.71 & 0.63 & 0.50 & 0.44 & 0.44 \\
\hline $\mathrm{Ti}$ & n.d & n.d. & n.d & n.d & n.d & $\mathrm{n}, \mathrm{d}$. & n.d & 0.04 & 0.04 & 0.04 \\
\hline $\mathrm{Al}$ & n.d & n.d. & n.d & n.d & n.d & $\mathrm{n}, \mathrm{d}$. & n.d & 0.24 & 0.24 & 0.23 \\
\hline $\mathrm{Fe}$ & n.d & n.d. & n.d & n.d & n.d & n,d. & n.d & 0.34 & 0.31 & 0.28 \\
\hline $\mathrm{U}$ & 0.00 & 0.00 & 0.00 & 0.00 & 0.00 & 0.00 & 0.00 & 0.00 & 0.00 & 0.00 \\
\hline Th & 0.07 & 0.07 & 0.03 & 0.03 & 0.08 & 0.01 & 0.03 & 0.01 & 0.01 & 0.01 \\
\hline $\mathrm{Y}$ & 0.03 & 0.02 & 0.02 & 0.03 & 0.05 & 0.04 & 0.08 & 0.00 & 0.00 & 0.00 \\
\hline $\mathrm{Ce}$ & 0.54 & 0.56 & 0.52 & 0.53 & 0.38 & 0.55 & 0.55 & 0.13 & 0.14 & 0.14 \\
\hline $\mathrm{Nd}$ & 0.20 & 0.19 & 0.19 & 0.19 & 0.13 & 0.18 & 0.19 & 0.04 & 0.04 & 0.04 \\
\hline
\end{tabular}




\section{Continued}

\begin{tabular}{cllllllllll}
\hline La & 0.22 & 0.22 & 0.21 & 0.22 & 0.18 & 0.29 & 0.24 & 0.06 & 0.05 & 0.05 \\
$\mathrm{Pr}$ & 0.06 & 0.06 & 0.06 & 0.05 & 0.04 & 0.05 & 0.05 & 0.00 & 0.01 & 0.01 \\
$\mathrm{Sm}$ & 0.03 & 0.04 & 0.03 & 0.03 & 0.02 & 0.02 & 0.03 & 0.00 & 0.00 & 0.00 \\
$\mathrm{Gd}$ & 0.02 & 0.02 & 0.02 & 0.02 & 0.01 & 0.01 & 0.03 & 0.00 & 0.00 & 0.00 \\
$\mathrm{Dy}$ & 0.01 & 0.00 & 0.01 & 0.01 & 0.01 & 0.00 & 0.01 & 0.01 & 0.01 & 0.01 \\
$\mathrm{Ho}$ & 0.00 & 0.00 & 0.00 & 0.00 & 0.00 & 0.00 & 0.00 & 0.00 & 0.00 & 0.00 \\
$\mathrm{Er}$ & 0.00 & 0.00 & 0.00 & 0.00 & 0.00 & 0.00 & 0.00 & 0.00 & 0.00 & 0.00 \\
$\mathrm{Yb}$ & 0.00 & 0.00 & 0.00 & 0.00 & 0.00 & 0.00 & 0.00 & 0.00 & 0.00 & 0.00 \\
$\mathrm{Lu}$ & 0.00 & 0.00 & 0.00 & 0.00 & 0.00 & 0.00 & 0.00 & 0.06 & 0.06 & 0.06 \\
$\mathrm{~F}$ & 0.32 & 0.30 & 0.53 & 0.30 & 2.67 & 2.25 & 2.01 & 2.56 & 2.52 & 2.50 \\
$\mathrm{Total}$ & 2.82 & 2.82 & 2.94 & 2.77 & 4.66 & 4.33 & 4.12 & 7.74 & 4.44 & 5.27 \\
$(\mathrm{La} / \mathrm{Sm}) \mathrm{n}$ & 3.89 & 3.59 & 3.74 & 4.44 & 5.88 & 8.48 & 4.33 & 2.58 & 2.27 & 1.79 \\
$(\mathrm{La} / \mathrm{Nd}) \mathrm{n}$ & 1.86 & 2.21 & 2.09 & 2.10 & 2.58 & 2.98 & 2.38 & 2.42 & 2.58 & 2.98 \\
\hline
\end{tabular}

LREE (6 wt\%) in the studied xenotime grains. In addition, monazites show some occurrences of HREE in minor or trace amounts (HREE $+\mathrm{Y}_{2} \mathrm{O}_{3}$ between 1.3 to $2.5 \mathrm{wt} \%)$.

\section{Discussion}

\subsection{The Fractionation of the REE-Bearing Minerals}

Kymi granite stock in southeastern Finland and especially the related greisens are enriched in REE, In, F and Sn and contain various sulphide mineralization such as sphalerite, galena, chalcopyrite and arsenopyrite. An examination of the distribution of REE in the studied rapakivi granites revealed that a large proportion of the LREE were hosted in monazite and bastnäesite, whereas the HREE were commonly hosted in xenotime, thorite and zircon (Figure 4). Enrichment of REE in some of the selected samples of the studied Kymi granite stock is confined to highly fractionated portion at the rapakivi granites. Therefore, the coexisting volatile-rich fluid at the later stage, which play an important role in the genesis of REE-mineralization in the wiborgite and Kymi granite stock. Figures 4(a)-(c) show chondrite-normalized REE patterns of the monazite, bastnäesite and allanite from the studied rapakivi granites. The differences in the slope of the chondrite-normalized REE patterns are represented by the difference in $(\mathrm{La} / \mathrm{Sm})_{\mathrm{cn}}$ and $(\mathrm{La} / \mathrm{Nd})_{\mathrm{cn}}$ values. The monazite grains of the studied granitic rocks show higher $\left[(\mathrm{La} / \mathrm{Sm})_{\mathrm{cn}}: 3.74-4.90\right]$ and lower $\left[(\mathrm{La} / \mathrm{Nd})_{\mathrm{cn}}: 1.86-2.21\right]$ values, respectively. Moreover, the chondrite-normalized REE profiles of bastnäesite and allanite are similar to that of monazite, with higher $[(\mathrm{La} / \mathrm{Sm}) \mathrm{cn}: 4.33-8.48]$ and lower $\left[(\mathrm{La} / \mathrm{Nd})_{\mathrm{cn}}: 2.38\right.$ - 2.98] values for bastnäesite, and higher $\left[(\mathrm{La} / \mathrm{Sm})_{\mathrm{cn}}: 4.44\right.$ $7.74]$ and lower $\left[(\mathrm{La} / \mathrm{Nd})_{\mathrm{cn}}: 1.69-2.58\right]$ values for allanite (Table 5). Thus, the chondrite-normalized ratios reflect the degree of fractionation in REE-bearing minerals. The REE patterns in xenotime, thorite and zircon vary the most. Chondrite- 

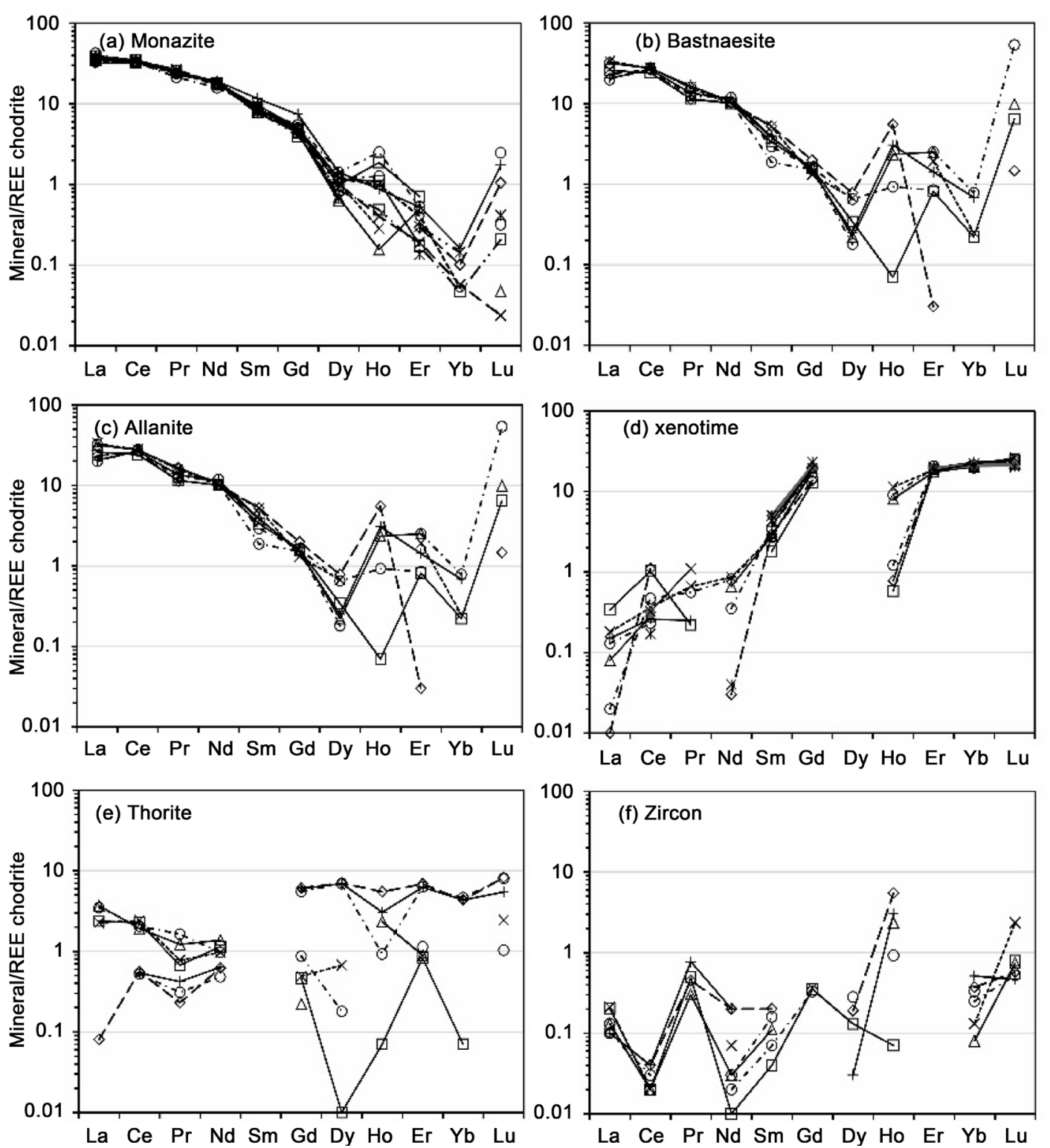

Figure 4. Chondrite-normalized patterns of distribution of the REE in the minerals studied. Monazite, bastnäesite, allanite, xenotime, thorite and zircon.

normalized REE patterns show that individual HREE tends to be enriched in specific minerals (Figures $4(\mathrm{~d})-(\mathrm{f})$ ).

In the studied monazite grains from the Kymi granite stock, the main constituents are La, Ce and $\mathrm{Nd}$ (La $0.21-0.25 \mathrm{apfu}, \mathrm{Ce} 0.52-0.57 \mathrm{apfu}, \mathrm{Nd} 0.19-0.21$ apfu) $\mathrm{PO}_{4}$, with HREE $+\mathrm{Y}$ elements between $0.05-0.07 \mathrm{apfu}$. Most of the monazite grains analysed in this study contain more than 95 mol\% LREE, and less than $5 \mathrm{~mol} \%$ HREE $+\mathrm{Y}$ (Table 5). Xenotime composed mainly of $\mathrm{YPO}_{4}$ with some occurrences of Dy and Gd (Y 0.86 - 0.96 apfu, Dy 0.07 - 0.09 apfu, Yb 0.06 - $0.07 \mathrm{apfu}$ ). Xenotime shows a common composition with strongly dominant $\mathrm{Y}$, HREE $\gg$ LREE, and very low $\mathrm{Si}, \mathrm{Pb}, \mathrm{Th}, \mathrm{U}$, and $\mathrm{Ca}$ contents. Xenotime from Kymi granite stock contain $71-76 \mathrm{~mol} \% \mathrm{YPO}_{4}, 16-27 \mathrm{~mol} \%$ HREE and $6-8$ 
mol\% LREE ('Table 6).

The solid solution between monazite and xenotime is limited between $6-8$ mol\% LREE in xenotime and between $4-5$ mol\% HREE $+\mathrm{Y}$ in monazite (Figure 5). The LREE content of melts buffered by xenotime and HREE content of melts buffered by monazite have a strong temperature dependence, which can be used as a geothermometer [20]. The mole fraction of HREE + Y in monazite ranges between $4-5 \mathrm{~mol} \%$, corresponding to low temperatures of $500^{\circ} \mathrm{C}-600^{\circ} \mathrm{C}$ (Mogilevsky, 2007 in figure 9). The solid solutions of monazite and xenotime in the studied Kymi granite complex were equilibrated hydrothermally at peak temperatures ranging from $500^{\circ} \mathrm{C}-600^{\circ} \mathrm{C}$. The essential point is that the concentrations of HREE $+\mathrm{Y}$ in monazite and LREE ( $\mathrm{La}$ to $\mathrm{Sm}$ ) in xenotime are strongly dependent upon the growth temperature and degree of metamorphism [21] [22].

\subsection{Mineralization of Indium-Bearing Minerals}

Mineralized greisen veins and deposits generally occur in association with highly fractionated granitic intrusions [9] [23]. The highly evolved Kymi granite complex contains several greisen veins within the zonal structure, and they occur in

Table 6. Chemical composition of xenotime and thorite from the Kymi granite stocks, wt\%.

\begin{tabular}{|c|c|c|c|c|c|c|c|c|}
\hline \multirow{2}{*}{$\begin{array}{l}\text { Sample } \\
\text { Mineral }\end{array}$} & \multicolumn{2}{|c|}{ L434R1/18.95 } & \multicolumn{2}{|c|}{ L443R3/133.40 } & \multicolumn{2}{|c|}{ L434R1/20.95 } & \multicolumn{2}{|c|}{ L434R1/18.95 } \\
\hline & Xnt1 & Xnt2 & Xnt3 & Xnt4 & Thr1 & Thr2 & Thr3 & Thr4 \\
\hline $\mathrm{SiO}_{2}(w \mathrm{t} \%)$ & 0.52 & 0.50 & 0.48 & 0.20 & 20.74 & 18.23 & 18.06 & 16.06 \\
\hline $\mathrm{P}_{2} \mathrm{O}_{5}$ & 32.27 & 32.24 & 33.60 & 34.36 & 1.11 & 1.00 & 1.56 & 2.86 \\
\hline $\mathrm{PbO}$ & 0.17 & 0.12 & 0.39 & 0.37 & 0.28 & 0.19 & 2.36 & 0.14 \\
\hline $\mathrm{UO}_{2}$ & 0.31 & 0.35 & 0.47 & 0.15 & 1.62 & 1.76 & 0.99 & 8.29 \\
\hline $\mathrm{ThO}_{2}$ & 0.26 & 0.29 & 0.46 & 0.17 & 68.12 & 70.19 & 69.57 & 49.09 \\
\hline $\mathrm{Y}_{2} \mathrm{O}_{3}$ & 42.66 & 41.84 & 38.72 & 40.88 & 0.23 & 0.12 & 0.38 & 10.03 \\
\hline $\mathrm{Nd}_{2} \mathrm{O}_{3}$ & 0.02 & 0.06 & 0.42 & 0.21 & 0.58 & 0.82 & 0.69 & 0.37 \\
\hline $\mathrm{La}_{2} \mathrm{O}_{3}$ & 0.40 & 0.52 & 0.00 & 0.05 & 1.07 & 1.14 & 0.73 & 0.02 \\
\hline $\mathrm{Pr}_{2} \mathrm{O}_{3}$ & 0.54 & 0.54 & 0.00 & 0.03 & 0.20 & 0.15 & 0.08 & 0.03 \\
\hline $\mathrm{Sm}_{2} \mathrm{O}_{3}$ & 4.55 & 4.77 & 3.96 & 0.72 & 0.19 & 0.11 & 0.11 & 0.35 \\
\hline $\mathrm{Gd}_{2} \mathrm{O}_{3}$ & 0.00 & 0.08 & 5.27 & 5.12 & 0.23 & 0.06 & 0.12 & 1.58 \\
\hline $\mathrm{Dy}_{2} \mathrm{O}_{3}$ & 4.57 & 4.67 & 5.53 & 5.49 & 0.06 & 0.00 & 0.00 & 2.26 \\
\hline $\mathrm{Ho}_{2} \mathrm{O}_{3}$ & 0.58 & 0.81 & 0.56 & 0.61 & 0.00 & 0.17 & 0.01 & 0.39 \\
\hline $\mathrm{Er}_{2} \mathrm{O}_{3}$ & 3.63 & 3.90 & 4.10 & 3.90 & 0.24 & 0.19 & 0.17 & 1.44 \\
\hline
\end{tabular}


Continued

\begin{tabular}{|c|c|c|c|c|c|c|c|c|}
\hline $\mathrm{F}$ & 0.15 & 0.17 & 0.11 & 0.14 & 0.87 & 1.21 & 1.49 & 0.56 \\
\hline Total & 95.90 & 96.19 & 99.57 & 98.15 & 99.47 & 99.12 & 99.92 & 96.86 \\
\hline \multicolumn{9}{|c|}{ Structural formulae based on 4 oxygen atoms } \\
\hline Si (apfu) & 0.050 & 0.047 & 0.045 & 0.019 & 1.050 & 0.967 & 0.959 & 0.957 \\
\hline $\mathrm{P}$ & 1.304 & 1.304 & 1.330 & 1.373 & 0.024 & 0.022 & 0.035 & 0.072 \\
\hline $\mathrm{Ca}$ & 0.004 & 0.005 & 0.000 & 0.003 & 0.122 & 0.128 & 0.106 & 0.044 \\
\hline $\mathrm{Pb}$ & 0.004 & 0.003 & 0.010 & 0.009 & 0.004 & 0.003 & 0.034 & 0.002 \\
\hline $\mathrm{U}$ & 0.007 & 0.008 & 0.010 & 0.003 & 0.018 & 0.021 & 0.012 & 0.110 \\
\hline Th & 0.006 & 0.006 & 0.010 & 0.004 & 0.785 & 0.848 & 0.840 & 0.666 \\
\hline $\mathrm{Y}$ & 0.957 & 0.939 & 0.850 & 0.906 & 0.003 & 0.001 & 0.005 & 0.140 \\
\hline $\mathrm{Ce}$ & 0.004 & 0.005 & 0.004 & 0.004 & 0.015 & 0.015 & 0.018 & 0.005 \\
\hline $\mathrm{Nd}$ & 0.000 & 0.001 & 0.007 & 0.004 & 0.005 & 0.008 & 0.007 & 0.004 \\
\hline $\mathrm{La}$ & 0.007 & 0.009 & 0.000 & 0.001 & 0.010 & 0.011 & 0.007 & 0.000 \\
\hline $\operatorname{Pr}$ & 0.009 & 0.009 & 0.000 & 0.001 & 0.002 & 0.001 & 0.001 & 0.000 \\
\hline $\mathrm{Sm}$ & 0.075 & 0.078 & 0.064 & 0.012 & 0.002 & 0.001 & 0.001 & 0.004 \\
\hline $\mathrm{Gd}$ & 0.000 & 0.001 & 0.082 & 0.080 & 0.002 & 0.001 & 0.001 & 0.016 \\
\hline Dy & 0.070 & 0.072 & 0.083 & 0.084 & 0.000 & 0.000 & 0.000 & 0.022 \\
\hline Ho & 0.009 & 0.012 & 0.008 & 0.009 & 0.000 & 0.001 & 0.000 & 0.004 \\
\hline Er & 0.054 & 0.059 & 0.060 & 0.058 & 0.002 & 0.002 & 0.001 & 0.013 \\
\hline $\mathrm{Yb}$ & 0.062 & 0.063 & 0.067 & 0.069 & 0.000 & 0.000 & 0.000 & 0.008 \\
\hline $\mathrm{Lu}$ & 0.010 & 0.010 & 0.008 & 0.010 & 0.000 & 0.000 & 0.000 & 0.002 \\
\hline F & 0.047 & 0.052 & 0.034 & 0.042 & 0.140 & 0.204 & 0.251 & 0.105 \\
\hline Total & 2.680 & 2.684 & 2.671 & 2.690 & 2.184 & 2.234 & 2.277 & 2.175 \\
\hline$(\mathrm{La} / \mathrm{Sm}) \mathrm{n}$ & 0.054 & 0.068 & 0.000 & 0.041 & 3.450 & 6.673 & 4.158 & 0.044 \\
\hline$(\mathrm{La} / \mathrm{Nd}) \mathrm{n}$ & 31.750 & 18.556 & 0.000 & 0.429 & 3.557 & 2.679 & 2.079 & 0.129 \\
\hline
\end{tabular}

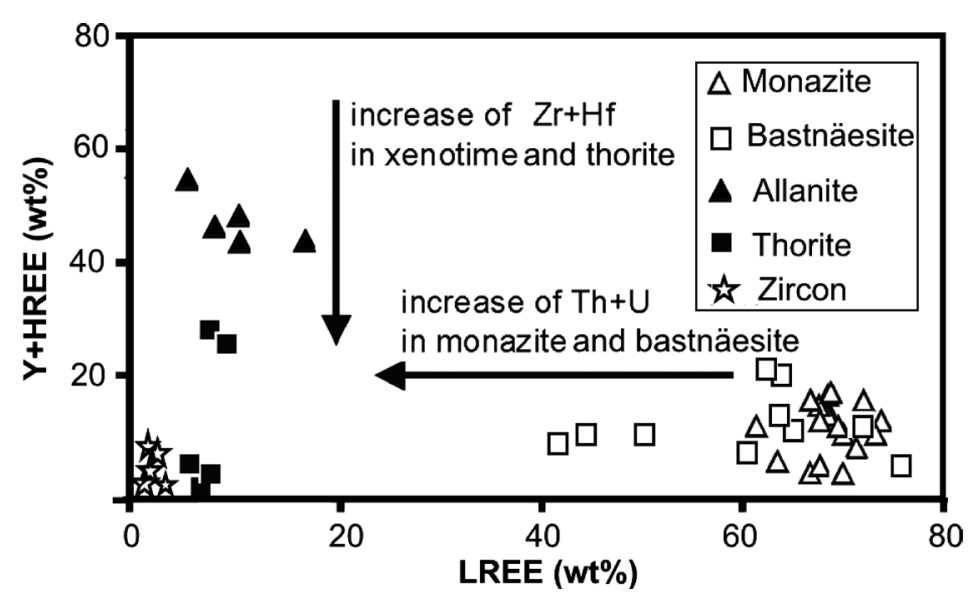

Figure 5. Limited substitution between monazite and xenotime. In this figure, LREE represents $\mathrm{La}+\mathrm{Ce}+\mathrm{Pr}+\mathrm{Nd}+\mathrm{Sm}+\mathrm{Gd}$, whereas HREE represents $\mathrm{Dy}+\mathrm{Ho}+\mathrm{Er}+\mathrm{Yb}+\mathrm{Lu}$. 
the surrounding rapakivi granites. These intrusions are commonly enriched in REE, indium, lithium, fluorine and beryllium, and contain sulphide minerals of $\mathrm{Cu}, \mathrm{Pb}, \mathrm{Zn}, \mathrm{As}, \mathrm{Sn}$ and $\mathrm{W}$ [24]. Greisenization was recognized as a multi-step of hydrothermal alterations followed by chloritization, silicification and sericitization [25].

Recently, Valkama et al. [8] (2016) defined three types of greisen that are hosted by both the Kymi granite stock and surrounding wiborgite granites and can be grouped according to the metal association as follows: Li-As-W-Zn-Mn, $\mathrm{Cu}-\mathrm{As}-\mathrm{In}$, and $\mathrm{Pb}-\mathrm{Zn}$. The second and third types of greisens (Cu-As-In, and $\mathrm{Pb}-\mathrm{Zn}$ ) consist mainly indium (up to $1490 \mathrm{ppm}$ ) and sulphides (very high In/Zn ratios), enabling the formation of a proper indium mineral: roquesite. The present study also evaluated in similar vein types located in wiborgite granites up to 3 $\mathrm{km}$ from the Kymi stock contact (Figure 1). The uniform NW-SE strike pattern of the greisen veins inside and near the Kymi stock indicates that the greisen vein formation was tectonically controlled in the nearly consolidated granite body and the surrounding wiborgite. This feature is also noted in the western parts of the wiborgite massif in the Sarvlaxviken, Liljendal, Artjärvi and Sääskjärvi areas [6] [7] [8] [26].

The main accessory minerals hosted in these greisens are fluorite, cassiterite, wolframite, genthelvite, galena, sphalerite and chalcopyrite. The present study demonstrated that indium was initially concentrated in galena, and we have discovered new occurrences of the copper-indium sulphide mineral roquesite (nominally $\mathrm{CuInS}_{2}$ ) as minute grains included in galena. This enrichment of galena in indium indicates the availability of $\mathrm{Cu}, \mathrm{In}, \mathrm{Zn}$ and $\mathrm{Pb}$ as isomorphic substitutions in natural sulphide systems. The indium substitution in galena are unknown, although it might be expect a considerable solid solution between galena and roquesite $\left(\mathrm{Pb}^{2+} \mathrm{S}^{2-} \leftrightarrow \mathrm{Cu}^{+} \mathrm{In}^{3+} \mathrm{S}^{2-}\right)$, given their comparable structures. An investigation into the solubility of indium in hydrothermal synthesized galena and sphalerite was carried out by [27]. He reported that the solubility of indium in galena increased from approximately $17 \mathrm{ppm}$ at $350^{\circ} \mathrm{C}$ to $100 \mathrm{ppm}$ at $550^{\circ} \mathrm{C}$. The solubilities agree well with the data on indium concentrations in natural galena crystals. Here, roquesite in selected samples was most likely a primary component of the mineralization, as demonstrated by its occurrence in multiple galena crystals. Most previous studies on galena have focused on elements such as Ag, $\mathrm{Bi}$ or $\mathrm{Sb}$, which are known to occur at relatively high concentrations in some galena specimens. We focused on the occurrences of indium (In) and copper $(\mathrm{Cu})$, and also explained the relationship between In-rich sphalerite (roquesite) and galena. The alteration during the late hydrothermal and supergene stages in the wiborgite and Kymi granite complex, probably through a supergene process, enhanced the formation of roquesite (nominally $\mathrm{CuInS}_{2}$ ) in galena. Some trace elements $(\mathrm{Cu}, \mathrm{In}, \mathrm{Zn}, \mathrm{As}, \mathrm{Sn}, \mathrm{Ag}$ and $\mathrm{Bi})$ can substitute into the crystal lattice of galena at various concentrations. Indium incorporation into the galena structure probably occurred according to the relationship $\mathrm{Pb}^{2+} \mathrm{S}^{2-} \leftrightarrow \mathrm{Cu}^{+} \mathrm{In}^{3+} \mathrm{S}^{2-}$, although 
the release of $\mathrm{Zn}$ from the crystal lattice of sphalerite present in galena is also possible.

\section{Conclusions}

1) The occurrence of greisen intrusions within the Kymi granite stock and as well in the surrounding wiborgite rapakivi granites, such as albite-topaz-REE microgranite dikes and mineralization greisen veins of $\mathrm{F}-\mathrm{Sn}-\mathrm{Zn}-\mathrm{Pb}-\mathrm{Cu}$, is due to primary magmatic fluids and postmagmatic processes, which strongly enriched in fluorine and tin, respectively. These intrusions host In-REE minerals, with roquesite $\left(\mathrm{CuInS}_{2}\right)$ being a major indium carrier, whereas monazite (Ce), allanite (Ce), Bastnäesite $(\mathrm{Ce})$, xenotime- $(\mathrm{Y})$ and thorite are the main REE carriers.

2) Mineralogical investigations show the dominating LREE-bearing minerals of monazite, allanite and bastnäesite, while the HREE-bearing minerals include thorite, xenotime and zircon. F-rich granitic melt has been intruded and cross-cutting magmatic system at later stages, which plays an important role in the genesis of REE mineralization.

3) The studied Kymi granite stock may include variable amounts of sulphides, such as galena, sphalerite, pyrite and chalcopyrite. These sulphide assemblages occur in variable amounts and may be precipitated from hydrothermal solutions during the late stage of crystallization as filling of fractures, of open vugs and of the spaces within the studied rapakivi granites. Indium association with sulphide, mainly galena, can be distinguished on the basis of a microanalytical study of the sulphide assemblages. The results demonstrate that indium prefers galena over sphalerite and chalcopyrite. This could be due to possible substitution of copper and indium with lead in galena. A probable substitution is $\mathrm{Pb}^{2+} \mathrm{S}^{2-} \leftrightarrow \mathrm{Cu}^{+} \mathrm{In}^{3+} \mathrm{S}^{2-}$, which gives a similar ionic radius and the same charges. Furthermore, the strong correlation between copper, iron and zinc in galena could also play an important role. However, another likely suggestion is that zinc presented in galena is replaced by indium, although the coupled substitution $2\left(\mathrm{~Pb}^{2+} \mathrm{Zn}^{+}\right)=\mathrm{Cu}^{+} \mathrm{In}^{3+}$ is also present.

\section{References}

[1] Lukkari, S., Thomas, R. and Haapala, I. (2009) Crystallization of the Kymi Topaz Granite Stock within the Wiborg Rapakivi Granite Batholith, Finland: Evidence from Melt Inclusions. Canadian Mineralogist, 47, 1359-1374. https://doi.org/10.3749/canmin.47.6.1359

[2] Rämö, O.T. and Haapala, I. (2005) Rapakivi Granites. In: Lehtinen, M., Nurmi, RA. and Rämö, O.T., Eds., Precambrian Geology of Finland-Key to the Evolution of the Fennoscandian Shield, Elsevier B.V., Amsterdam. https://doi.org/10.1016/S0166-2635(05)80013-1

[3] Al Ani, T., Kärkkäinen, N., Sarapää, O., Tiainen, M. and Kuusela, J., (2014) REE-Y-Th-U-Rich Accessory Minerals in Selected Samples of the Rapakivi Granites in Onkamaa, Suomenniemi and Luumäki, Southern Finland. GTK Research Report, Geologian Tutkimuskeskus, Espoo, 44 p. 
[4] Al-Ani, T. (2015) REE-Bearing Minerals in the Rapakavi Granite, Southern Finland. Open Geosciences, 7, 646-662. https://doi.org/10.1515/geo-2015-0057

[5] Burke, E.A.J. and Kieft, C. (1980) Roquesite and In-Bearing Sphalerite from Långban, Bergslagen, Sweden. Canadian Mineralogist, 18, 361-363.

[6] Sundblad, K. and Ahl, M. (2008) Metallogeny of Indium in the Svecofennian Domain. 33rd International Geological Congress, Oslo, 6-14 August 2008, Abstract CD-ROM.

[7] Cook, N.J., Sundblad, K., Valkama, M., Nygård, R., Ciobanu, C.L. and Danyushevsky, L. (2011) Indium Mineralisation in A-Type Granites in Southeastern Finland. Insights into Mineralogy and Partitioning between Coexisting Minerals. Chemical Geology, 284, 62-73. https://doi.org/10.1016/j.chemgeo.2011.02.006

[8] Valkama, M., Sundblad, K., Nygårdb, R. and Cook, N. (2016) Mineralogy and Geochemistry of Indium-Bearing Polymetallic Veins in the Sarvlaxviken Area, Lovisa, Finland. Ore Geology Reviews, 75, 206-219. https://doi.org/10.1016/j.oregeorev.2015.12.001

[9] Schwarz-Schampera, U. and Herzig, P. (2002) Indium. Geology, Mineralogy, and Economics. Springer-Verlag Berlin, Heidelberg, New York. https://doi.org/10.1007/978-3-662-05076-7

[10] Ohthta, E. (1991) Polymetallic Mineralization at the Toyoha Mine, Hokkaido, Japan. Mining Geology, 41, 279-295.

[11] Ohthta, E. (1989) Occurrence and Chemistry of Indium-Containing Minerals from the Toyoha Mine, Hokkaido, Japan. Mining Geology, 36, 355-372.

[12] Gaskov, I.V., Vladimirov, A.G., Khanchuk, A.I., Pavlova, G.A. and Gvozdev, V.I. (2017) Distribution of Indium in Ores of Some Base Metal and Tin-Sulfide Deposits in Siberia and the Russian Far East. Geology of Ore Deposits, 59, 56-67. https://doi.org/10.1134/S1075701517010032

[13] Gaskov, I.V., Pavlova, G.G., Vladimirov, A.G. and Gvozdev, V.I. (2014) Indium and Other Trace Elements in the Ores of the Sulfide-Polymetallic and Tin-Sulfide Deposits of Siberia and Far East. Geology and Mineral Resources of Siberia, No. 3s, 67-71. http://www.jourgimss.ru/en/SitePages/catalog/2014/03s1/201403s1.aspx

[14] Al Ani, T., Ahtola T. and Kuusela, J. (2017) Critical Metals Mineralization in the Late-Stage Intrusions of Wiborg Batholith, Southern. GTK Research Report, 45 p. http://tupa.gtk.fi/raportti/arkisto/21_2017.pdf

[15] Chen, B. and Jahn, B.M. (2002) Genesis of Post-Collisional Granitoids and Basement Nature of the Junggar Terrane, NW China: Nd-Sr Isotope and Trace Element Evidence. Journal of Asian Earth Sciences, 23, 691-703. https://doi.org/10.1016/S1367-9120(03)00118-4

[16] Förster, H.-J. (1998) The Chemical Composition of REE-Y-Th-U-rich Accessory Minerals from Peraluminous Granites of the Erzgebirge-Fichtelgebirge Region, Germany. I. The Monazite-(Ce)-Brabantite Solid Solution Series. American Mineralogist, 83, 259-272. https://doi.org/10.2138/am-1998-3-409

[17] Cressey, G.G., Wall, F. and Cressey, B.A. (1999) Differential REE Uptake by Sector Growth of Monazite. Mineralogical Magazine, 63, 813-828.

[18] Pandey, M., Pant, N.C. and Kumar, S. (2013) Criteria to Distinguish between Regional and Contact Zone Monazite: A Case Study from Proterozoic North Delhi Fold belt (NDFB), India. Episodes, 36, 275-289.

[19] Williams-Jones, A.E., Samson, I.M. and Olivo, G.R. (2000) The Genesis of Hydrothermal Fluorite-REE Deposits in the Gallinas Mountains, New Mexico. Economic 
Geology, 95, 327-342. https://doi.org/10.2113/gsecongeo.95.2.327

[20] Mogilevsky, P. (2007) On the Miscibility Gap in Monazite-Xenotime Systems. Physics and Chemistry of Minerals, 34, 201-214. https://doi.org/10.1007/s00269-006-0139-1

[21] Heinrich, W., Andrehs, G. and Franz, G. (1997) Monazite-Xenotime Miscibility Gap Thermometry: I. An Empirical Calibration. Journal of Metamorphic Geology, 15, 3-17. https://doi.org/10.1111/j.1525-1314.1997.t01-1-00052.x

[22] Gratz, R. and Heinrich, W. (1997) Monazite-Xenotime Thermobarometry: Experimental Calibration of the Miscibility Gap in the Binary System $\mathrm{CePO}_{4}-\mathrm{YPO}_{4}$. American Mineralogist, 82, 772-780. https://doi.org/10.2138/am-1997-7-816

[23] Sinclair, W.D., Kooiman, G.J.A., Martin, D.A. and Kjarsgaard, I.M. (2006) Geology, Geochemistry and Mineralogy of Indium Resources at Mount Pleasant, New Brunswick, Canada. Ore Geology Reviews, 28, 123-145. https://doi.org/10.1016/j.oregeorev.2003.03.001

[24] Haapala, I. and Ojanperä, P. (1972) Genthelvite-Bearing Greisens in Southern Finland. Bulletin of the Geological Society of Finland, 259, 22 p.

[25] Pirajno, F. (1992) Hydrothermal Mineral Deposits Principal and Fundamental Concepts for the Exploration Geologist. Springer-Verlag, Berlin. https://doi.org/10.1007/978-3-642-75671-9

[26] Haapala, I. and Lukkari. S. (2005) Petrological and Geochemical Evolution of the Kymi Stock, a Topaz Granite Cupola within the Wiborg Rapakivi Batholith, Finland. Lithos, 80, 347-362. https://doi.org/10.1016/j.lithos.2004.05.012

[27] Kissin, S.A. (1972) An Investigation of the Solubility of Indium in Hydrothermally Synthesized Galena and Sphalerite. Canadian Mineralogist, 11, 575. 